\title{
B 型慢性肝炎での抗ウイルス療法後の長期予後の指標としての
}

\section{albumin receptor 活性（pHSA-BA）之 pre-S 抗原の臨床的意義}

\begin{abstract}
武田＼cjkstart誠*
要 旨：抗ウイルス療法を施行した B 型慢性肝炎を対象に, pHSA-BA と pre-S抗原を EIA 法により測定し，これらの臨床的意義を検討した. pHSA-BA 価と pre-S 抗原価は $\mathrm{r}=0.961$ と よい相関を示した。抗ウイルス療法後にALT の正常化が持続する症例では, pHSA-BA 価と pre-S 抗原価はともに0.5以下であった. 1 年以上経過を観察しえた 28 例のうち治療直後にこれ らのマーカーが0.5以下に低下したのは 8 例であり，5ち 3 例(38\%)では pHSA-BA 価と pre-S 抗原価の再上型に伴いALT の異常を認めた。いずれのマーカーも0.5以下を維持した 5 例では 経過観案期間中に ALT は持続的に正常であった。一方，0.5以下に低下しなかった20例中17例 (85\%)で ALT の異常が認められ，亏ち5 例では HBe 抗原が持続的に陰性化していた，以上の 結果より，抗ウイルス療法後の長期予後を加味した効果判定には pHSA-BA や pre-S 抗原の測 定がきわめて有用であると考学られた。
\end{abstract}

索引用語： B 型慢性肝炎 抗ウイルス療法 pHSA-BA pre-S 抗原

\section{緒言}

現在までB型慢性肝炎に対して種々の抗ウイルス 療法が施行され, 効果の判定は $\mathrm{HBe}$ 抗原の陰性化あ るいは HBe 抗体への seroconversion (SC) を認める ことが有効とされている.しかし，HBe 抗体へSCし た例の中にも血清トランスフミナーゼの異常が持続 し, 組織学的にも改善が認められない例が少なからず 存在する $\mathrm{HBe}$ 抗原・抗体系の推移のみでは肝炎の鎮静化括よび 長期予後を十分に評価しているとはい亲ない，最近， B 型肝炎ウイルス (HBV) が polymerized human serum albumin (pHSA) とそれに対するレセブターを 介して特異的に肝細胞に接着することが知られてい る.また,これらのレセプターはHBVのクリフランス とも関係していることが指摘されている. pHSA に対 するレセブターは HBV の gene S の上流の163のアミ ，酸残基からなる pre-S領域にコードされてい る pHSA に対する binding activity (pHSA-BA) および pre-S 項域にコードされているポリペプタイド (pre-S 抗原)を enzyme immunoassay (EIA) 法にて測定し,

* 京都府立医科大学第 3 内料

<受付日63年 7 月25日 $>$
抗ウイルス療法後の長期予後を予測するマーカーとな りらるか否かを検討したので報告する。

対象および方法

対象は抗ウイルス療法を施行した HBe 抗原陽性の B 型慢性肝炎30例である。性別は男性25例，女性 5 例 で年齢は25歳から47歳でその平均年齢は32.9歳であっ た. 全例で治療前に肝生検を施行し, その診断はョー ロッバ分類り飞従った．組織学的には慢性活動性肝炎 (CAH) が29例，慢性持続性肝炎 (CPH) が 1 例であ る。抗ウイルス療法前の HBe 抗原 (cut-off index)の 平均値は4.5, DNA-P の平均值は897dpm, 血清 alanine aminotransferase (ALT) の平均値は127Karmen units (KU) であった (Table 1). 抗ウイルス療 法は、インターフェロン(IFN) 単独投与が27例，ステ ロイド短期離脱と IFN との併用療法が 3 例である. Table 2 にIFN の種類, 投与量, 投与総量を記載した. 治療前战よび治療後の各種ウイルスマーカーの測定 はー20두で凍結保存した血清にて測定した。 pHSA-BA の測定は，Tsuji $5^{10)}$ の方法に従い測定し た. すなわち, HBs モノクローナル抗体を固相化した ポリスチレン製マイクロタイタープレートにサンプル 血清を10倍希积して添加し, HBs 抗原を固相抗体上結 合させた後、ペルオキシダーゼで標識した pHSA 溶液 を添加し反応させ，o-phenylene diamine, urea perox- 
Table 1 Characteristics of patients with antiviral treatment

\begin{tabular}{|c|c|}
\hline No. of patiants & 30 \\
\hline Sox $(M: F)$ & $25: 5$ \\
\hline$A g \cdot(y r)$ & $32.9=8.1^{4}$ \\
\hline $\begin{array}{r}\text { Histology } \\
\text { CAH } \\
\text { CPH }\end{array}$ & $\begin{array}{r}29 \\
1\end{array}$ \\
\hline HBeAg (RIA) & $4.5 \pm 1.6^{a}$ \\
\hline DNA polymerase $(\mathrm{dpm})^{\mathrm{b}}$ & $897 \pm 1394^{\circ}$ \\
\hline ALT $(K U) c$ & $127 \pm 111^{\circ}$ \\
\hline
\end{tabular}

Table 2 Schedules of interferon administration.

\begin{tabular}{|c|c|c|c|}
\hline & $n$ & total dose $\left(\times 10^{6} \mid U\right)$ & period (days) \\
\hline $\begin{array}{l}\text { IFN }-\alpha \\
(\mathrm{JRCBC})\end{array}$ & 6 & $84-184$ & $35-52$ \\
\hline $\begin{array}{l}\text { IFN }-\theta \\
\text { (Toray, Mochida) }\end{array}$ & 12 & $84-240$ & $15-42$ \\
\hline $\begin{array}{l}r \text { IFN-aA } \\
\text { (Takeda-Roche) }\end{array}$ & 2 & 477 & 34 \\
\hline $\begin{array}{l}\text { HLBI } \\
\text { (Sumitomo-Welcome) }\end{array}$ & 7 & $168 \sim 210$ & 35 \\
\hline PSL+IFN- $a$ & 3 & 150 & $45 \sim 55$ \\
\hline
\end{tabular}

Table 3 Method for assaying pHSA-BA.

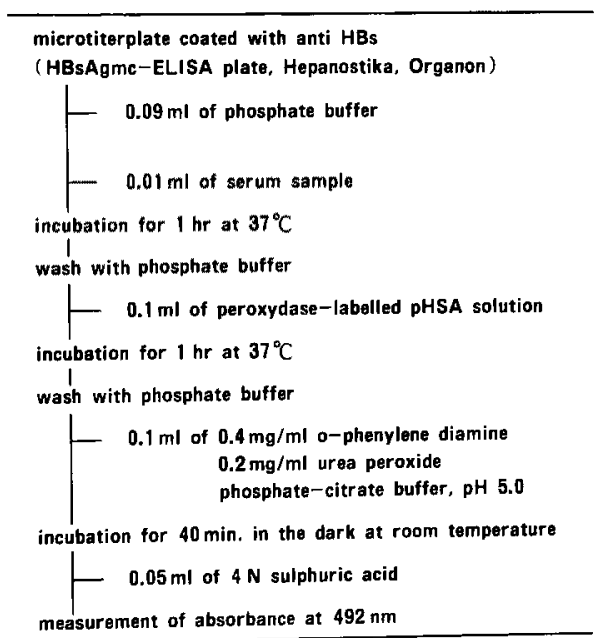

ide にて発色後, Titertec Multiscan にて492nm の吸 光度を測定しその酵素活性とした（Table 3). Pre-S

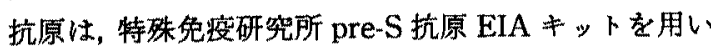
て測定した．抗 pre-Sモノクローナル抗体を固相化し たボリスチレン製マイクロタイタープレートにサンプ
Table 4 Method of dot hybridization for assaying serum HBV DNA.

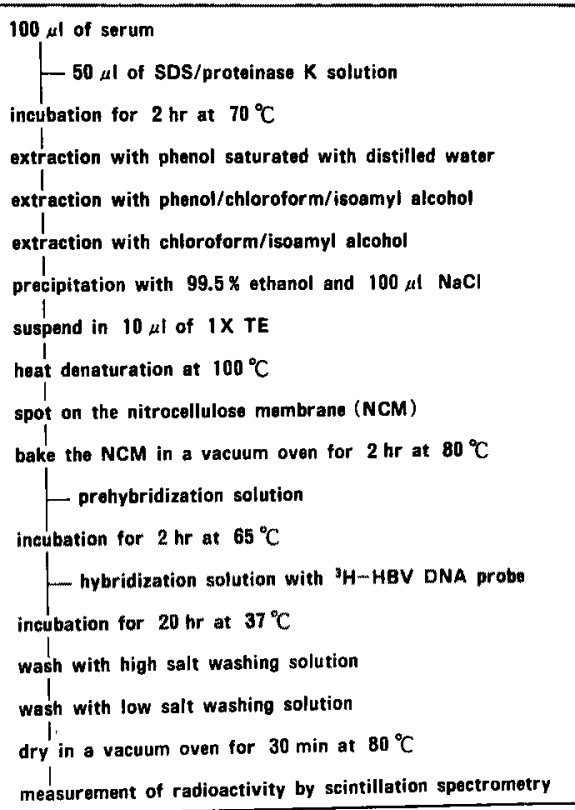

ル血清を10倍希釈して添加し, pre-S抗原を固相抗体 と結合させ，ペルオキシダーゼで標識した抗 pre-S モ ノクローナル抗体と反応させた後, pHSA-BA と同様 の方法で発色させ測定し，その測定値を pre-S 抗原価 とした。 $\mathrm{HBe}$ 抗原・抗体は radioimmunoassay (RIA) 法で測定し，その判定は鈴木ら ${ }^{11)}$ の基準に従い行なっ た。DNA-P は Kaplan ら ${ }^{12)}$ 方法で測定した，HBV DNAは， dot hybridization 法にて測定した。すなわ ら，サンプル血清 $100 \mu l$ を SDS/proteinase K で処理 後, phenol 抽出, エタノールにて核酸を沈股させ $10 \mu l$ の1X TE bufferにて溶解させ熱処理により1本鎖と し,ニトロセルロース膜に吸着させ vaccum ovenにて $80^{\circ} \mathrm{C}$ で加熱し固定後, nick translation 法により $\left[{ }^{3} \mathrm{H}\right]$ dTTPで標識した HBV DNAをプロープをして hybridization を行ない, シンチレーションカウンター で放射活性を測定した後，既知量の組み換え $\mathrm{HBV}$ DNA を段階希釈して得られた検量線を用いて定量化 した(Table 4). 推計学的な有意差の検定は, Student の $\mathrm{t}$-検定にて行なった。

\section{成 績}

1. HBe 抗原・抗体の推移と ALT の関係からみた 抗ウイルス療法の有効性の評価

抗ウイルス療法を施行した30例中，治療後に $\mathrm{HBe}$ 
Table 5 ALT and HBV associated viral markers before antiviral treatment.

\begin{tabular}{|c|c|c|}
\hline & $\begin{array}{c}\text { Responder " } \\
\text { (Loss of } \mathrm{HB} \odot \mathrm{Ag} \text { ) }\end{array}$ & $\begin{array}{l}\text { Non-responder } \\
\text { (Positive HBeAg) }\end{array}$ \\
\hline No. of pationts & 11 & 19 \\
\hline AL.T $(K \mathbf{K})^{b}$ & $200 \pm 152$ & $85 \pm 41^{*}$ \\
\hline HBøAg (cut-off index) & $4.4 \pm 1.5$ & $4.7 \pm 1.6$ \\
\hline DNA polymerase (dpm)c & $768 \pm 1375$ & $1058 \pm 1418$ \\
\hline HEV DNA $(\mathrm{pg} / \mathrm{ml})^{d}$ & $1742 \pm 1014$ & $2540 \pm 1459$ \\
\hline pHSA-BA (OD $492 \mathrm{~mm})$ & $1.86 \pm 0.55$ & $1.82 \pm 0.69$ \\
\hline pre-S $A_{g}(O D 492 \mathrm{~nm})$ & $1.90 \pm 0.59$ & $1.94 \pm 0.74$ \\
\hline
\end{tabular}

values are mean \pm SD. * $p<0.01$ : compared to responder

- 5 cases seroconverted to anti $\mathrm{HBe}$ and 6 wero seronegative for $\mathrm{HBe} A g$

balanine aminotransferase : normal $<40$ Karmen units

cpositive $\geqq 80 \mathrm{dpm}$

dpositive $\geqq 80 \mathrm{pg} / \mathrm{mt}$

Table 6 Deterioration of ALT, pHSA-BA and pre-S Ag after treatment.

\begin{tabular}{|c|c|c|c|c|}
\hline \multirow[b]{2}{*}{$\begin{array}{l}\text { pHSA-BA } \\
\text { pro-S Ag }\end{array}$} & \multicolumn{3}{|c|}{ Responder } & \multirow{2}{*}{$\begin{array}{l}\text { Non-responder } \\
\qquad n=17\end{array}$} \\
\hline & $\begin{array}{l}S N \\
n=6\end{array}$ & $\begin{array}{l}\mathrm{sc} \\
\mathrm{n}=5\end{array}$ & $\begin{array}{l}\text { total } \\
n=11\end{array}$ & \\
\hline A $0.5>$ & $1 / 3$ & $0 / 1$ & $1 / 4(25 x)$ & $2 / 4(50 x)$ \\
\hline B $0.5<$ & $2 / 3$ & $3 / 4$ & $5 / 7(71 x)$ & $12 / 13(92 x)$ \\
\hline
\end{tabular}

抗原が持続的に陰性化した responder 群（R 群）は11 例であった。 また， $\mathrm{HBe}$ 抗原が持続的に陽性ないしは 一過性に陰性化した non-responder 群（N 群）は19例 であった， R 群と N 群間での治療前の ALTおよび各 種ウイルスマーカーをそれぞれの平均值 (mean土SD)

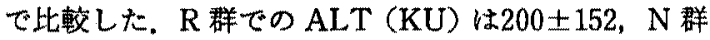
でのそれは85土41と R 群で有意 $(\mathrm{p}<0.01)$ に高值で あった。 HBe 抗原 (cut-off index)は $R$ 群で4.4土1.5, $\mathrm{N}$ 群で4.7士1.6であった。 DNA-P (dpm) はR群で $768 \pm 1,375, \mathrm{~N}$ 群で1,058 $\pm 1,418$, HBV DNA（pg/

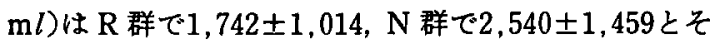
れぞれ R 群で低い傾向がみられたが，ばらつきが大き く，両群間で有意差は認めなかった。 pHSA-BA 価と pre-S 抗原価はそれぞれ R 群で1.86さ0.55と1.90士

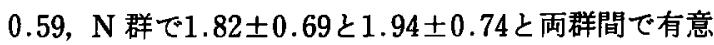
差を認めなかった（Table 5).

抗ウイルス療法施行後 1 年以上の経過を観察しえた のは28例である。このうち $\mathrm{HBe}$ 抗原が持続的に陰性 化した R 群は11例であった。 また, HBe 抗原が持続陽 珄の N 群は17例であった。 $\mathrm{R}$ 群11例のらち HBe 抗原 の陰性化 (seronegative; SN) したのは 6例, HBe 抗 体へSC したのは 5 例であった，治療後のALTの推
移を両群間で比較すると， $\mathrm{R}$ 群では11例中 5 例 (45\%) にALT の持続的な正常化を認め，6 例(55\%) KALT の增悪を認めた。ALTが増悪した 6 例のうち 3 例が $\mathrm{SN}$ 例で, 残りの 3 例が SC 例であった. N 群では17例 中14例 (82\%)にALT の増悪を認めたが，残りの 3 例 (18\%)ではALT の持続的な正常化と肝炎の鎮静化を 認めた (Table 6).

2. 抗ウイルス療法による pHSA-BA 価と pre-S 抗 原価の推移

$\mathrm{R}$ 群と $\mathrm{N}$ 群別に抗ウイルス療法前後の pHSA-BA 価と pre-S 抗原価の推移を比較検討した．治療前には 両群間で差は認めなかったが，治療啳では $\mathrm{R}$ 群で pHSA-BA 価と pre-S 抗原価はともに減少する例が多 く, 治療後の平均值 (mean \pm SD) は, pHSA-BA 価

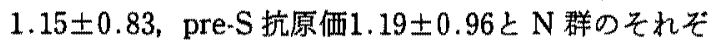

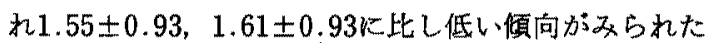
が両群間で有意差は認めなかった. $\mathrm{N}$ 群でも $\mathrm{R}$ 群之同 様に治療後に減少傾向を認める例があるも，ほとんど の例で高値を持続していた（Fig. 1).

一方, pHSA-BA 価と pre-S 抗原価との相関関保を 調べる目的で抗ウイルス療法前後扰よび経過観察期間 中に測定したサンブル血清のらち at randomに選ん だ50 pointsについて pHSA-BA 価と pre-S 抗原価の 相関性を検討すると相関係数 $\mathrm{r}=0.961$ とよい相関が 得られた (Fig. 2).

3. pHSA-BA 価およU゙pre-S抗原価の推移と ALT との関係からみた抗ウイルス療法の有効性の評 価

抗ウイルス療法の現時点での治療目的は肝炎を鎮静 化させ $\mathrm{HBe}$ 抗体陽性の無症候性 HBVキャり丁の状 態にすることと考えられる。著者が測定した HBe 抗 体陽性無症候性 HBV キャリア 8 例の pHSA-BA 価 は0.09から0.34で, pre-S抗原価は0.11から0.28と全 例で pHSA-BA 価および pre-S 抗原価はともに0.5以 下であった。 また，抗ウイルス療法後に pHSA-BA 価 および pre-S 抗原価が减少した例では R 群おょび N 群で, pHSA-BA 価と pre-S 抗原価はともに0.5以下に 低下していた (Fig. 1). そこで抗ウイルス療法施行後 1 年以上の経過を観察しえた $\mathrm{R}$ 群の 11 例と $\mathrm{N}$ 群の 17 例について pHSA-BA 価と pre-S 抗原価が治療後に ともに0.5以下に低下した群 (A 群) と0.5以上の群 (B 群)とに分類すると A 群は 8 例, B 群は20例であった。 それぞれの群別に治療前の ALTと各種ウイルスマー カーをそれぞれの平均值 (mean士SD) で比較した，A 

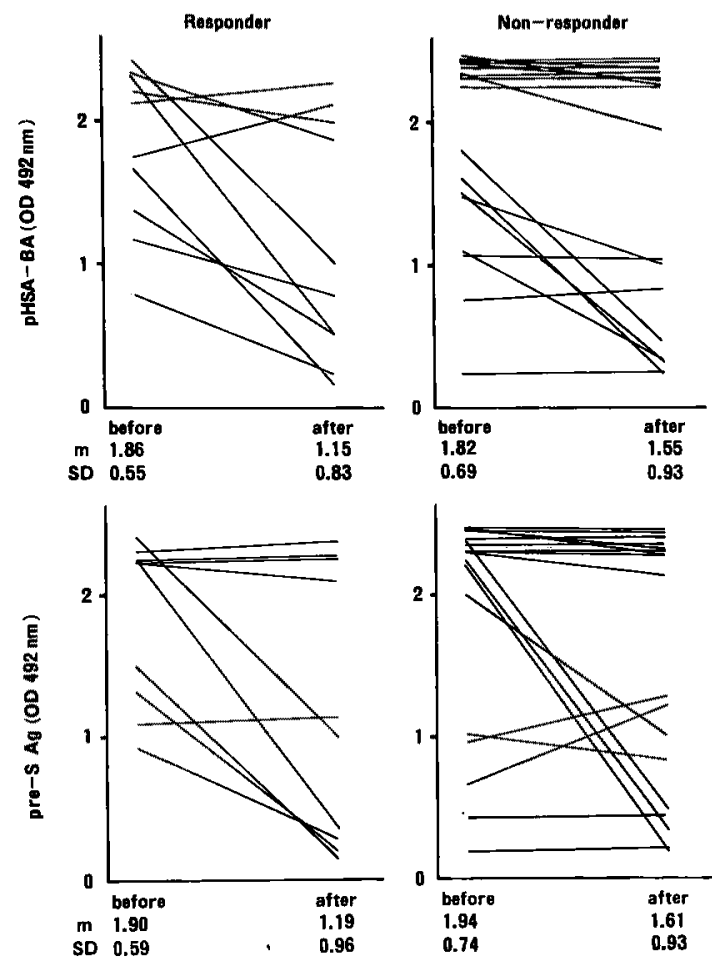

Fig. 1 pHSA-BA and pre-S Ag before and after antiviral treatment.

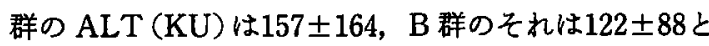
$\mathrm{A}$ 群が高い傾向を示したが両群間で有意差は認めな かった. DNA-P (dpm) はA 群が97士88, B 群が $1,149 \pm 1,553$ 之 A 群が有意 $(\mathrm{p}<0.002)$ 飞低值であっ た. HBe 抗原 (cut-off index) Ł HBV DNA $(\mathrm{pg} / \mathrm{m} l)$

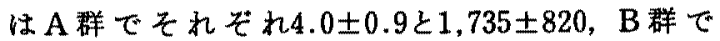
$4.7 \pm 1.6$ と2,233土1,225といずれるA 群で低い傾向 を示したが有意差は認めなかった。 pHSA-BA 価は A

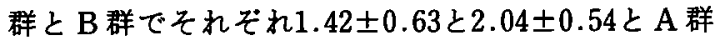
で有意 $(p<0.05)$ に低値を示した。 また，pre-S 抗原 価もそれぞれの群で $1.46 \pm 0.77$ 2.10士0.58であり pHSA-BA 価と同様の傾向を示したものの有意差は認 めなかった， A，B両群での治療後の $\mathrm{HBe}$ 抗原・抗体 の推移を検討すると A 群での SC 例は 1 例， SN 例は 3 例であり, HBe 抗原持続陽性は 4 例であった。一方， $\mathrm{B}$ 群ではSC 例と SN 例はそれぞれ 4 例と 3 例であ ク，HBe 抗原持綕陽性は13例であった．また両群間で 治療後の肝炎の增悪例を検討すると, A 群では 8 例中 3 例 (38\%) で ALT の再上昇とDNA.Pお゙び HBV DNA と HBe 抗原の再陽性化を認めた。一方，B群で

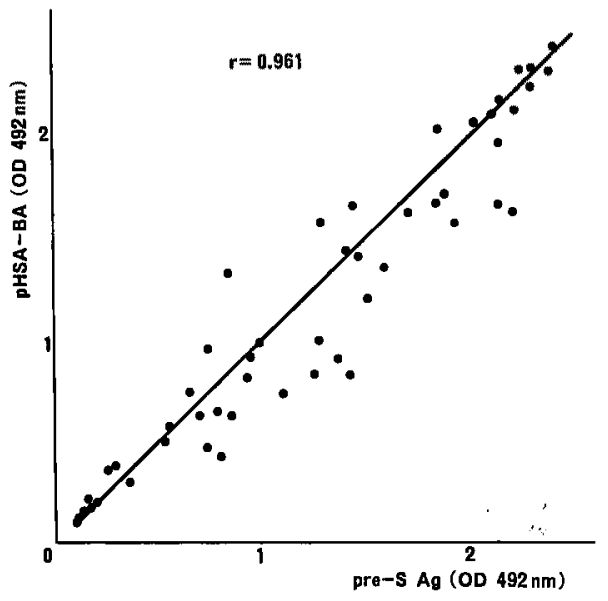

Fig. 2 Correlation between pHSA-BA and pre-S $\mathrm{Ag}$.

Table 7 ALT and HBV associated viral markers before and after treatment.

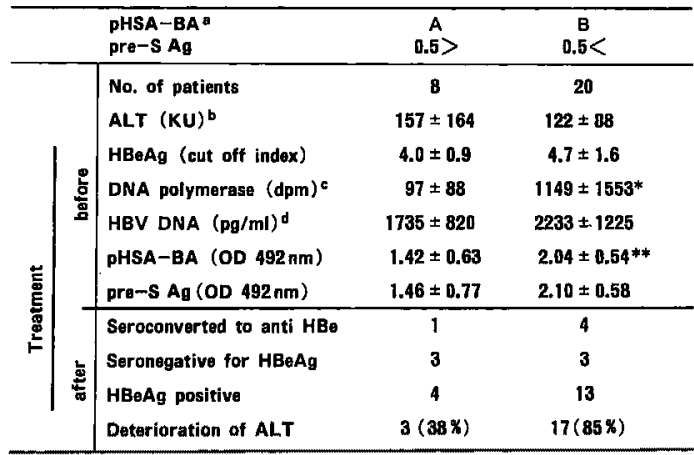

values are mean \pm SD, $* p<0.002, * * 0<0.05$; compared to $A$

"values are just after treatment

b ganinu amimotransforase : normal $<\mathbf{4 0}$ Karmen units

positive $\geq 80 \mathrm{dpm}$

dpositive $\geqq 80 \mathrm{pg} / \mathrm{ml}$

は20例中17例 (85\%) で同様の異常を伴った肝炎の増 悪を認めた (Table 7)。 また，両群での $\mathrm{HBe}$ 抗原・抗 体の推移と肝炎の増悪との関係を検討すると，A 群で は $\mathrm{HBe}$ 抗原が陰性化した 4 例中 1 例 (25\%) と $\mathrm{HBe}$ 抗原持続陽性 4 例中 2 例（50\%）に肝炎の増悪を認め たが，B 群では，SCした 3 例と SN の 2 例を含めた 7 例中 5 例 $(71 \%)$ で肝炎の増悪を認め, $\mathrm{HBe}$ 抗原が持 続陽性のものでは13例中12例（92\%）で肝炎の増悪が 認められた (Table 6). 以下，それぞれの代表例を呈 示する。

症例 1 (Fig. 3 上段)：29歳，男性，HBe 抗原陽性慢 性活動性肝炎. IFN 治療により DNA-P は陰性化し, 

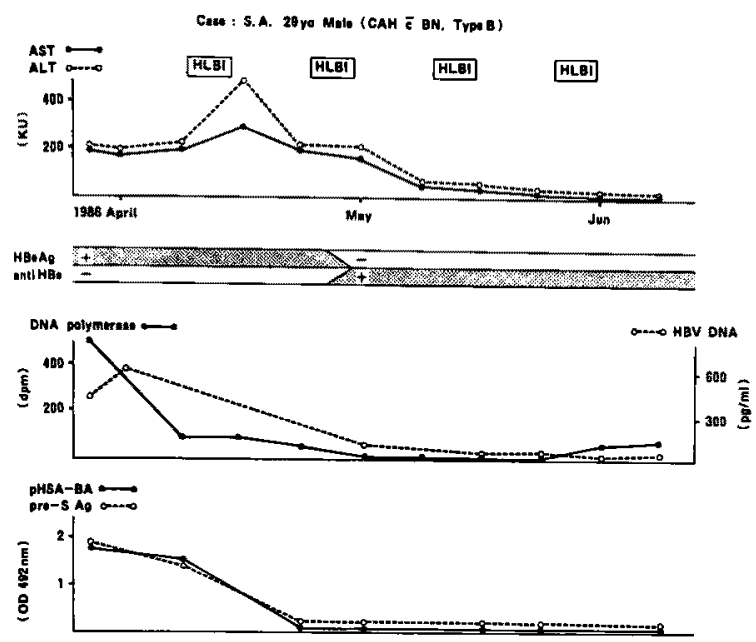

Can : M.K. $39_{\text {yo Malo (CAH, Troos) }}$

Case : J.A. 25 yo Femblo (GAH, Typa B)
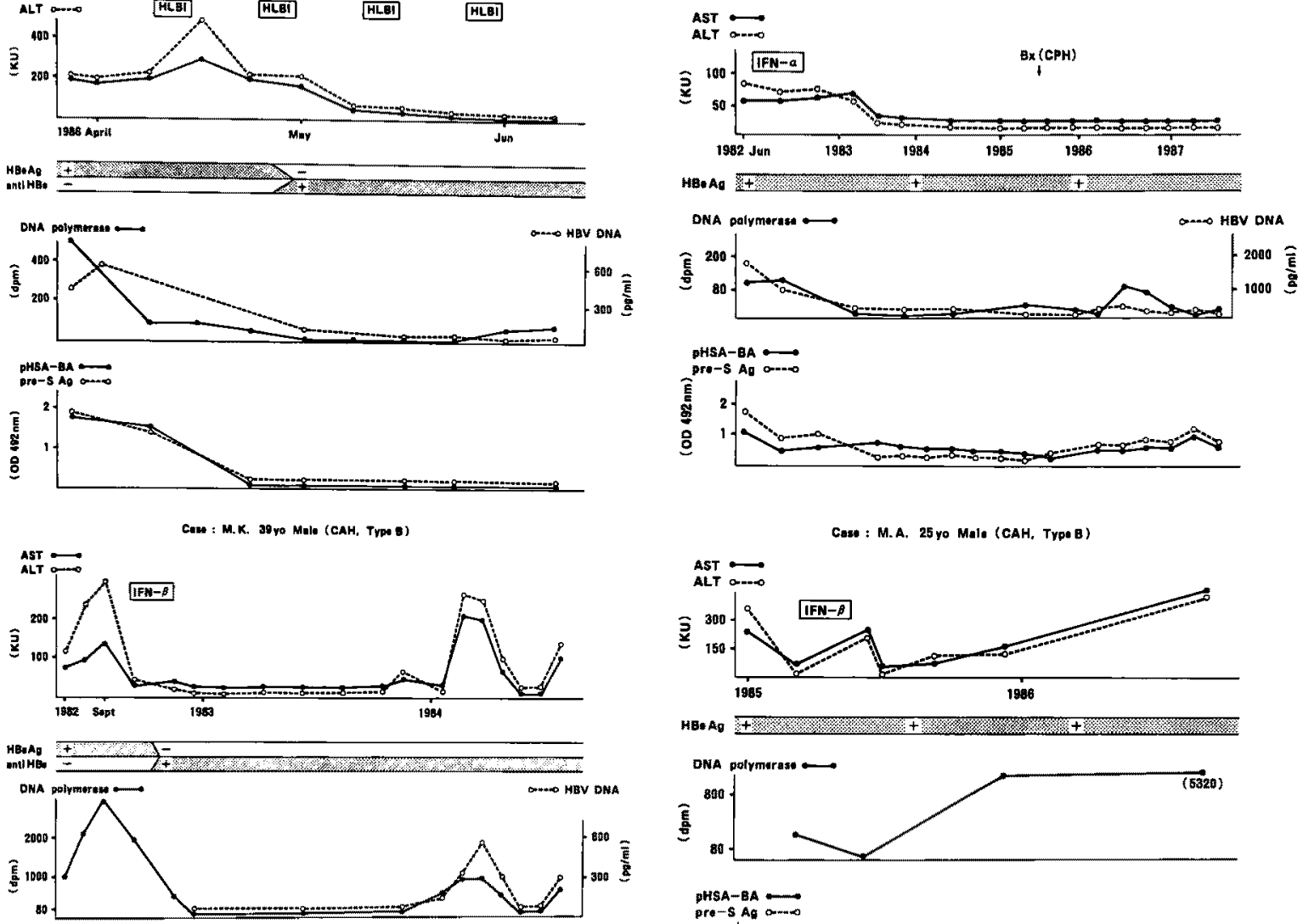

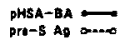
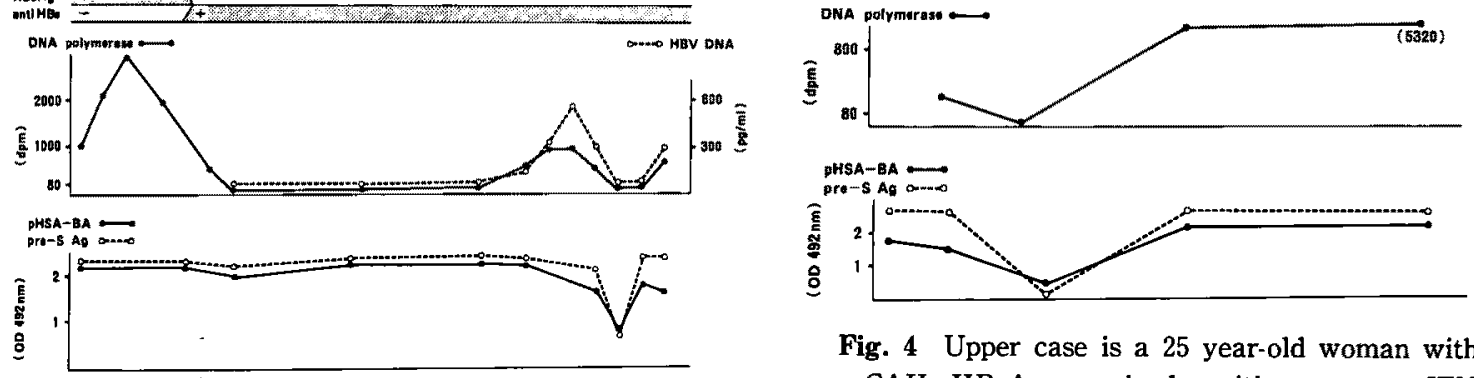

Fig. 4 Upper case is a 25 year-old woman with $\mathrm{CAH}$. $\mathrm{HBeAg}$ remained positive even on IFN teatment. However, ALT remained normal during a follow-up period. In this case, pHSA-BA and pre-S Ag decreased and remained under 0.5 after treatment.

Lower case is a 25 year-old man with $\mathrm{CAH}$. $\mathrm{HBeAg}$ remained positive in spite of IFN treatment. DNA-P became transiently negative and ALT elevated after treatment. In this case, pHSA-BA and pre-S Ag decreased transiently under 0.5 and then increased over 0.5 after treatment.

ALT remained normal. However, ALT elevated with positive DNA-P and HBV DNA one year after treatment. In this case, pHSA.BA and pre-S $\mathrm{Ag}$ remained over 0.5 in spite of IFN treatment.

ALT 正常化した，HBe 抗原の陰性化後に HBe 抗 体への SC 認めた。この例では pHSA-BA 洒および pre-S 抗原価はともに治療後に0.5以下に低下し，その

価を持統した，本例では，その後す肝機能の增悪を認 めていない.

症例 2 (Fig. 3 下段)：39藏, 男性, HBe 抗原陽性慢 性活動性肝炎. IFN 治療により, DNA-P DNA は持続的に陰性化した. ALT 正常範囲を持続 
ᄂ, $\mathrm{HBe}$ 抗原の陰珄化後に $\mathrm{HBe}$ 抗体心 SC し, その抗 体価は90\%以上の阻止率を維持していたが，1年後に DNA.P と HBV DNA の再上算に伴いALT の增悪 を認めた。この例ではIFN 治療後も pHSA-BA 価拉 よび pre-S 抗原価は0.5以上の高值を持続していた。

症例 3 (Fig. 4 上段)：25歳，女性, $\mathrm{HBe}$ 抗原陽性慢 性活動性肝炎. IFN 治療後す HBe 抗原が持続的に陽 性であり，DNA-P と HBV DNAはともに低值陽性で あるが，4 年以上の経過観察期間中に ALT の増悪を 認めていない，本例では pHSA-BA 価㧍よび pre-S 抗 原価はともに治療後に0.5以下となり，その後も低值を 持続していた，治療後の経時的肝生検で組織学的な改 善を認めた。

症例 4 (Fig. 4 下段)：25歳，男性，HBe 抗原陽性慢 性活動性肝焱，症例 3 之同様に $\mathrm{HBe}$ 抗原持繶陽性で あるが，IFN 治療により DNA.Pの㓌性化にともなっ て ALT も正常化した. pHSA-BA 価拉よび pre-S 抗 原価はともに0.5以下に低下したが, その後再び上昇し 高値を持続した. 本例ではpHSA-BA 価や pre-S 抗原 価の上昇に伴い DNA-P も再び高値となり ALT の増 悪を来した。

\section{考察}

B 型慢性肝炎の経過中に HBe 抗原が陰性化ないし は HBe 抗体へSCすると肝炎が鎮静化することはよ く知られている。しかし， $\mathrm{HBe}$ 抗体持続陽性例の中に もALTの異常を認める例があり，その頻度は $23 \%$ 〜32\%に認められる2 ${ }^{2 \sim 4}$.この上5な例では肝組織所見 の改善は認められず，むしろ組織学的にも增悪してい， る例が多い、1 従って，抗ウイルス㞠法の効果を $\mathrm{HBe}$ 抗原・抗体系のみから評価することは肝炎の治療とい う面からは不十分と思われる。

Matsuhashi ら ${ }^{13}$ によって HBs 抗原陽性患者の血 清中に pHSA に対する反応因子が存在することが報 告され，その後この因子は HBV 関連粒子の表面蛋白 上に存在する $\mathrm{pHSA}$ に対するレせプターであること が明らかとなった ${ }^{14)}$ 。また，肝細胞膜表面上にる同様の レセブターが存在することす知られて扣り ${ }^{15)}$ ，HBV がpHSA を介する系によって肝細胞と接着し核に入 り増殖を開始すると考えられている(10,14). B 型急性肝 炎に括いては，このレセプターに対する抗体が Dane 粒子そのものに対する抗体であり HBV の中和抗体と

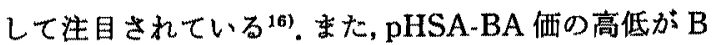
型急性肝炎の治癒期間むるいは慢性化と密接に関係し ているとの報告もみられる ${ }^{17,18)}$. pHSA そのものに対
する抗体む京た，同様の臨床的意義を有している199. 従って，pHSA 招上びpHSA に対するレセブターは HBV のクリアランスに重要な役割を演じていると考 えられる。また， pHSAに対するレセプター活性は gene Sの上流にある pre-S領域にコードされてい $ろ^{5 \sim 8)}$. 今回の成績では, pHSA-BA 価と pre-S 抗原価 は $\mathrm{r}=0.961$ と非常によい相関関係が認められ， pHSA-BA 価と pre-S 抗原価は密接な関係にあること が示された. HBe 抗体陽性の無症候性 HBV キャリフ では, pHSA-BA 価扰よび pre-S 抗原価はともに極め て低值である。一方，HBe 抗原陽性の $\mathrm{HBV} キ+y>$ では両者は高値であることが報告されている10,17). た，HBe 抗体陽性でも DNA.P H HBV DNA が陽性 の慢性肝炎では肝炎の活動性が高いことも指摘されて いる ${ }^{1,20)}$. pHSA-BA 価や pre-S 抗原価は, 慢性肝炎, 旰硬变と病態が進行するにつれ，DNA.Pや HBV DNA と同様に低值となる傾向がみられ ${ }^{10,17)}$ ，DNA-P やHBV DNA ともよい相関関係がみられる10,14,18)こ とより HBV の新しい増殖マーカーとして注目されて いる.

今回の成續では，抗ウイルス療法後に $\mathrm{HBe}$ 抗原の 持続的な陰性化を認めたのは28例中11例であり，その らち 6 例 (55\%) でその後の経過観察期間中に ALT の 増悪を認めた。 また $\mathrm{ALT}$ の増悪は $\mathrm{HBe}$ 抗体へ $\mathrm{SC} し$ た 5 例中 3 例 $(60 \%)$ でる認められた。一方，HBe 抗 原が持続陽性のものでは17例中14例 (82\%) に ALT の 異常が持続したが，らち 3 例(18\%)でALT の持続的 な正常化がみられた。しかし，HBe 抗原の有無とは関 係なく pHSA-BA 価や pre-S抗原価の面から抗ウイ ルス療法の奻果を検討すると，ALT が持続的に正常 化した例では pHSA-BA 価および pre-S 抗原価は任 とんどの例で0.5以下であった，そこで pHSA-BA 価 と pre-S 抗原価が治療後0.5以下に低下するものを抗 ウイルス療法の有効群とし，0.5以上を無効群として検 討した成績では，持続的に0.5以下を維持しえない例で は全例でALT の増悪がみられた。一方，治療後に0.5 以下に低下しその值を維持する例では13カ月から72カ 月間の経過観察期間中に ALT の悪化は 1 例も認めな かった. 治療後も0.5以上を持続する無效群では20例中 17例(85\%)で ALTの異常がみられ，うち 5 例は $\mathrm{HBe}$ 抗原が持続的に陰性化していた，以上のことょり，抗 ウイルス療法の効果判定には肝炎の鎮静化を含めた判 定基準が必要である，その意味からも治療後の持続的 なALT の正常化が効果判定の一項目となる必要があ 
り、治療後の予後を加味した判定には pHSA-BA 価や pre-S 抗原価の測定がきかめて有用であることが今回 の成績で明らかとなった，従って，抗ウイルス療法の 評価判定には， HBe 抗原・抗体に加亲て pHSA-BA 価 や pre-S 抗原価を含めた総合的な判定が必要である. これらマーカーの測定は簡便であり，かつ結果の判定 が短時間でできることなど日常臨床上きわめて有用な 検查法であると思われる。 また, pHSA-BA 価と pre-S 抗原価との間にはきわめてよい相関関係が認められる ことより，臨床の場ではいずれか一方の測定のみで十

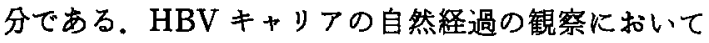
bHSA-BA 価が低值な例では高率に HBe 抗原の陰 性化, HBe 抗体への SC を認める ${ }^{10)} こ と か ゙$ 知られてお り，pHSA-BA 価は慢性肝炎のみならず $\mathrm{HBV} キ+リ$ フの follow-upkも有用な㭘査法である，以上のこと 上り，pHSA-BA や pre-S 抗原の測定法は簡便であり $\mathrm{B}$ 型慢性肝炎の種々の抗ウイルス療法の効果判定にも 有用と思われるため今後, 臨床の場で広く用いられる ことが期待される。

謝辞：御校閲を賜りました瀧野辰郎教授ならびに直接の 御指導と御校閲をいただいた明石市立市民病院内科部長， 奥野忠雄博士と本研究のために御協力いただいた第 3 内科 䀒炎タループの諸先生に深謝いたします。 また, ヘルオキシ ダーセ標識 $\mathrm{pHSA}$ を供与していただきました岡山大学第 1 内科，辻 孝夫数授に謝意を表します。尚本研究の一部は 厚生省嚾治性の肝炎調查研究班の補助によった。

本論文の要旨は, 第29回日本消化器病学会大会 (山梨県, 1987）にて発表した.

\section{文嗝}

1) Hadziyannis SJ, Lieberman HM, karvountzis GG, et al: Analysis of liver disease, nuclear $\mathrm{HBcAg}$, viral replication and hepatitis $B$ virus DNA in liver and serum of $\mathrm{HBeAg}$ vs. anti-HBe positive carriers of hepatitis $B$ virus. Hepatology $3: 656-662,1983$

2) Davis GL, Hoofnagle JH, Waggoner JG: Spontaneous reactivation of chronic hepatitis $B$ virus infection. Gastroenterology $86: 230-235$, 1984

3）奥野忠雄, 阿部芳道, 淿野辰郎：インターフェロン 単独療法後のB 型慢性肝炎の長期予後一抗的 几ス戍非投与例との比較炕上る湌討一。「B型慢性 䀒炎の治療：病態加らみた評洒」瀧野辰郎, 古田精 市編，国際医書出版，東京，80-87，1987
4）奥野忠雄，武田 誠，中島年和，他：HBe 抗体持 繶陽性 B 型慢性汗疾患での HBV の spontaneous reactivation の検討. 肝酮 $28: 399-404,1987$

5) Machida A, Kishimoto S, Ohnuma $\mathrm{H}$, et al: A hepatitis B surface antigen polypetide [P31] with the receptor for polymerized human as well as chimpanzee albumins. Gastroenterology 85 : 268-274, 1983

6) Neurath $A R$, Kent $S B H$, Strick $N$, et al: Hepatitis $B$ virus contains pre-S gene-encoded domains. Nature 315 : 154-156, 1985

7) Tiollasis $P$, Pourcel C, Dejean A : The hepatitis B virus. Nature $319: 489-495,1985$

8) Ohnuma $H$, Takahashi $K$, Kishimoto $S$, et al : Large hepatitis $B$ surface antigen polypeptides of Dane particles with the receptor for polymerized human serum albumin. Gastroenterology $90: 695-701,1986$

9) International Group : Acute and chronic hepatitis revisited. Lancet 2: 914-919, 1977

10) Tsuji $T$, Yamamoto $I$, Tsuchiya $M$, et al: Enzyme-linked immunosorbent assay for detection of receptors for polymerized human serum albumin on hepatitis B surface antigen particles. J Immunol Methods 73 : 357-366, 1984

11）鈴木宏，敛野四郎，市田文弘，他：Radioimmunoassay による e 抗原, e 抗体の測定について. 肝臟 $21: 1304-1309,1980$

12) Kaplan PM, Greenman RL, Gerin JL, et al : DNA polymerase associated with human hepa. titis B antigen. J Virol 12 : 995-1005, 1973

13) Matsuhashi $T$, Hosokawa $Z$ : Reactants to human serum albumin-coated red cells found in Au(1)-positive sera. Jpn J Exp Med 42: 183 $-185,1972$

14) Imai $M$, Yanase $Y$, Nojiri $T$, et al : A receptor for polymerized human and chimpanzee albumins on hepatitis $B$ particles co-occurring with HBeAg. Gastroenterology 76 : 242-247, 1979

15) Lenkei $R$, Onica $D$, Ghetie V : Receptors for polymerized albumin on liver cells. Experientia 33: 1046-1047, 1977

16) Alberti A, Pontisso P, Schiavon E, et al: An antibody which precipitates Dane particles in acute hepatitis type $\mathrm{B}$ : relation to receptor sites which bind polymerized human serum 
albumin on virus particles. Hepatology $4: 220$ $-226,1984$

17) Pontisso P, Alberti A, Bortolotti F, et al: Virus-associated receptors for polymerized human serum albumin in acute and in chronic hepatitis B virus infection. Gastroenterology $84: 220-226,1983$

18) Budkowska A, Dubreuil P, Capel F, et al: Hepatitis B virus pre-S gene-encoded antigenic specificity and anti-pre-S antibody: relationship between anti-pre-S response and recovery.
Hepatology $6: 360-368,1986$

19) Lee WM, McLeod L, Martin K, et al : Antibodies to polymerized human serum albumin in acute and chronic liver disease. Hepatology 7 : 906-912, 1987

20) Matsuyama $Y$, Omata M, Yokosuka O, et al : Discordance of hepatitis B e antigen/antibody and hepatitis $B$ virus deoxyribonucleic acid in serum. Analysis of 1063 sepcimens. Gastroenterology 89 : 1104-1108, 1985

\section{Binding activity to polymerized human serum albumin and pre-S antigen as predicting markers of prognosis in patients with chronic hepatitis $\mathrm{B}$, who were treated with antiviral agents}

\section{Makoto TAKEDA*}

We studied the clinical significance of the binding activity to polymerized human serum albumin (pHSA-BA) and pre-S antigen (pre-S Ag) as predicting markers of prognosis in patients with chronic hepatitis $\mathrm{B}(\mathrm{CHB})$ with antiviral tratment. The pHSA-BA and pre-S Ag were measured using enzyme immunoassay and their values were expressed as optical density at $492 \mathrm{~nm}$ (negative $<0.5$ ). There was a good correlation between pHSA-BA and pre-S Ag titers with $r=0.961$. The levels of pHSA-BA and pre-S Ag decreased under 0.5 in 8 patients (Group A) just after treatment, while in the remaining 20 patients (Group B), these levels were persistently over 0.5 after treatment. Five patients $(62 \%)$ in Group A had persistently normal alanine aminotransferase (ALT) levels during a follow-up period after treatment, while the remaining 3 had elevated ALT levels with elevation of pHSA-BA and pre-S Ag levels after treatment. Two of the these 5 patients were positive for HBeAg. Seventeen patients $(85 \%)$ in Group B had elevated ALT levels, with 2 being negative for $\mathrm{HBeAg}$ and 3 positive for anti $\mathrm{HBe}$. These results indicate that pHSA-BA and pre-S Ag may be useful markers in predicting the long-term prognosis of $\mathrm{CHB}$ patients with antiviral treatment.

\footnotetext{
* Third Department of Internal Medicine, Kyoto Prefectural University of Medicine (Kyoto)
} 